IZA DP No. 9003

Does Exposure to Economics Bring New Majors to the Field? Evidence from a Natural Experiment

Hans Fricke Jeffrey Grogger Andreas Steinmayr

April 2015 


\title{
Does Exposure to Economics Bring New Majors to the Field? Evidence from a Natural Experiment
}

\author{
Hans Fricke \\ Stanford University and University of St. Gallen \\ Jeffrey Grogger \\ University of Chicago and IZA \\ Andreas Steinmayr \\ University of Chicago and IZA
}

Discussion Paper No. 9003

April 2015

IZA
P.O. Box 7240
53072 Bonn
Germany

Phone: +49-228-3894-0

Fax: +49-228-3894-180

E-mail: iza@iza.org

Any opinions expressed here are those of the author(s) and not those of IZA. Research published in this series may include views on policy, but the institute itself takes no institutional policy positions. The IZA research network is committed to the IZA Guiding Principles of Research Integrity.

The Institute for the Study of Labor (IZA) in Bonn is a local and virtual international research center and a place of communication between science, politics and business. IZA is an independent nonprofit organization supported by Deutsche Post Foundation. The center is associated with the University of Bonn and offers a stimulating research environment through its international network, workshops and conferences, data service, project support, research visits and doctoral program. IZA engages in (i) original and internationally competitive research in all fields of labor economics, (ii) development of policy concepts, and (iii) dissemination of research results and concepts to the interested public.

IZA Discussion Papers often represent preliminary work and are circulated to encourage discussion. Citation of such a paper should account for its provisional character. A revised version may be available directly from the author. 
IZA Discussion Paper No. 9003

April 2015

\section{ABSTRACT \\ Does Exposure to Economics Bring New Majors to the Field? Evidence from a Natural Experiment ${ }^{*}$}

This study investigates how being exposed to a field of study influences students' major choices. We exploit a natural experiment at a Swiss university where all first-year students face largely the same curriculum before they choose a major. An important component of the first-year curriculum that varies between students involves a multi-term research paper in business, economics, or law. Due to oversubscription of business, the university assigns the field of the paper in a standardized way that is unrelated to student characteristics. We find that being assigned to write in economics raises the probability of majoring in economics by 2.7 percentage points, which amounts to 18 percent of the share of students who major in economics.

JEL Classification: A20, I20, 123

Keywords: major choice, economics, law, higher education, gender differences

Corresponding author:

Andreas Steinmayr

Harris School of Public Policy Studies

University of Chicago

1155 East 60th Street

Chicago, IL 60637

USA

E-mail: asteinmayr@uchicago.edu

\footnotetext{
* We thank Heinz Hofstetter, Alexander Schicho, and Felix van den Berg for invaluable support with the administrative data of the University of St. Gallen and for explaining the details of the institutional setting. Martin Eckhoff Andresen, Matthias Firgo, Julian Hsu, and Michael Lechner provided helpful comments on an earlier draft of the paper. We thank participants at seminars in St. Gallen and Aarhus for helpful discussions. Andreas Steinmayr received funding from the Swiss National Science Foundation through grant P2SGP1_155412.
} 


\section{Introduction}

A student's choice of college major has a large impact on her post-graduation labor market outcomes. ${ }^{1}$ Indeed, wage differences between some majors are as big as the wage gap between college and high school graduates (Altonji, Blom, and Meghir 2012). Besides economic considerations, recent studies suggest that students choose their field of study according to their tastes and abilities. ${ }^{2}$ These individual characteristics determine how much students enjoy their coursework and how much time and effort they invest towards their degree.

When students start college, they have imperfect knowledge about their tastes and abilities. They are then exposed to different fields of study through their coursework, which potentially helps them learn about their preferences and capabilities. In fact, one justification for late specialization is a better student-major match quality (Malamud 2010; Malamud 2011).

Yet we know little about how exposure to different fields affects a student's major decision. A principal reason is that students self-select into courses, that is, students choose courses in fields they think will interest them. As a result, using course selection to estimate the effect of exposure on major choice could overstate the importance of exposure.

This study analyzes how quasi-random exposure to academic fields affects major choice. Specifically, we study the impact of exposure to economics and law for students who are interested in business. To do so we exploit a natural experiment at a Swiss university.

The University of St. Gallen offers studies in the fields of Business, Economics, Law, Law and Economics, and International Affairs. Coursework for first-year students is almost identical irrespective of the student's intended major. However, in addition to coursework, the first-year curriculum involves a substantial first-year paper. Each student must write a paper in one of the three core fields: business, economics, or law. Students may state their preferences over fields, but because business is oversubscribed, students do not necessarily receive their preferred choice. To

1 See Arcidiacono (2004); Grogger and Eide (1995); Hamermesh and Donald (2008); Hastings, Neilson, and Zimmerman (2013); James et al. (1989); and Kirkebøen, Leuven, and Mogstad (2014).

2 Literature outside economics focuses on the role of aptitudes (i.e., major specific skills and abilities), tastes, and preferences (e.g. Malgwi, Howe, and Burnaby 2005). More recently, also the economics literature has started devoting more attention to these dimensions of the major decision. See Altonji (1993); Arcidiacono, Hotz, and Kang (2012); Montmarquette, Cannings, and Mahseredjian (2002); Stinebrickner and Stinebrickner (2014); Zafar (2011); and Zafar (2013). 
deal with the oversubscription problem, the university assigns the field of the first-year paper in a standardized way that is unrelated to student characteristics. This allows us to identify the effect of exposure to economics and law on subsequent major choice and on other student outcomes.

Among students whose preferred field is business, we find that being assigned to write a paper in economics increases the probability of majoring in economics by 2.7 percentage points. This is equal to 17.6 percent of the share of students who major in economics. Being assigned to write a law paper increases the probability of studying law by 1.6 percentage points. Furthermore, we find that being assigned to economics positively influences grades in introductory economic courses. Exposure to economics affects male students' major choices, whereas exposure to law affects female students' choices. Exposure to the field apparently does not help explain why relatively few women major in economics.

In a broader sense, our study relates to the policy discussions about major choices. For instance, a policy objective in the United States is to guide students towards STEM majors. ${ }^{3}$ Stinebrickner and Stinebrickner (2014) argue that greater exposure, by means of additional science courses, might lead to more science graduates. Our results suggest that such a policy might be worth exploring.

A few recent studies suggest that students' major choices are affected by coursework. Joensen and Nielsen (2015) provide evidence that high school math in combination with chemistry increases women's participation in health sciences and technical sciences. Zafar (2011) and Stinebrickner and Stinebrickner (2014) find that learning has not only a major-specific component but also a general component: by learning about their abilities or interests with respect to their pursued major, students also receive information about non-pursued majors. However, in these two studies students decide on their coursework, which in turn determines the fields about which students receive new information. That is, exposure to fields might be partly driven by unobserved tastes directly related to major choice. Wiswall and Zafar (2015) show that such tastes play an important role in students' major choices. An important advantage of our approach is that the institutional setting at the University of St. Gallen allows us to study exogenous exposure that is unrelated to students' characteristics.

The remainder of the paper is structured as follows. Section 2 introduces the institutional setting at the University of St. Gallen and the assignment mechanism. Section 3 describes the administrative

${ }^{3}$ For an overview of the discussion see Bettinger (2010). 
data and provides descriptive statistics. Section 4 explains the empirical framework. Section 5 presents the results and robustness checks. Section 6 concludes.

\section{Institutional setting}

\subsection{General background}

The University of St. Gallen is one of twelve public universities in Switzerland. All undergraduates declare a major close to the end of their first year. Table 1 shows that over three-fifths of the students enroll in business. Men make up 69\% of undergraduate students and the average age at enrollment is 20.2 years (not shown). Twenty-four percent are foreign nationals.

Table 1: Major enrollment by field

\begin{tabular}{lc}
\hline Major & \% enrolled in major \\
\hline Business & 61.7 \\
Economics & 15.3 \\
Law & 5.4 \\
International Affairs & 13.7 \\
Law \& Economics & 7.7 \\
\hline Note: Distribution of majors of students that completed first \\
year in first attempt. Shares don't add up to $100 \%$ as some \\
students are enrolled in two majors.
\end{tabular}

The first-year curriculum is almost identical for all students. Coursework includes one class each semester in each of the three core fields of business, economics, and law. These are large lectures that seat all first-year students at the same time. Students are also organized into discussion sections. Each discussion section consists of around 35 students and three teaching assistants, one in each core field. Discussion sections meet once a week on Fridays; the field that is covered in section rotates on a week-to-week basis. ${ }^{4}$ Students are assigned to their section for the entire first year, but teaching assistants may change in the second semester.

Besides coursework, a key part of the first-year curriculum is the first-year paper, which addresses a topic in one of the three core fields. The first-year paper is intended to provide students with an introduction to academic writing. It is supervised by one of the teaching assistants from the student's discussion section. The supervising teaching assistant sets the paper topic, supervises the student's work, and grades the paper. Teaching assistants are relatively free to assign specific topics within their field. Appendix 3 provides a sample list of topics from the three fields and information on the requirements and assessment criteria.

\footnotetext{
${ }^{4}$ See Appendix 2 for a simplified Friday schedule for different sections.
} 


\subsection{Assignment of the paper field}

The process used to assign students to the paper field is linked to the process used to assign students to discussion sections. During an orientation week that takes place immediately before the first semester starts, students are allocated points that they use to bid for their choice of discussion sections. Students' preferences are strongly related to the section's meeting time, since all discussion sections meet on Fridays. Most students place their bids after receiving information on the bidding process during the orientation week. ${ }^{5}$ Assignment to discussion sections then takes place at the end of the week.

Students are assigned to the field of their paper at the end of the first semester in mid-December and the paper is due close to the end of the second semester in April. Students may submit a preference ranking for the three fields in November. An example of such a ranking could be: 1 business, 2 economics, and 3 law. Preference rankings are processed on a section-by-section basis. Within each discussion section, one-third of students are assigned to business, one-third to economics, and one-third to law. As a result, the factors that determine the student's field assignment are: (i) the student's own preference ranking; (ii) the sort order in which students are processed within the section; and (iii) the distribution of preference rankings of other students in the section.

An example helps to clarify how the distribution of preferences and the student's sort order affect her assignment. Consider two sections with 36 students each. In both sections, the preference ranking of student number 13 is 1 business, 2 economics, and 3 law. In Section A, only six of the students sorted between one and twelve rank business first, so student 13 gets business. In Section B, all students between one and twelve rank business first, so student 13 is assigned her second choice, which is economics. Appendix 4 provides a more detailed description of the implementation of the assignment algorithm.

We were initially advised that the sort order of students within section was randomly assigned. Upon inspecting the source code of the program that makes the assignments, however, we discovered that the sort order is not based on a random number. Instead, the sort order is based on the inverse of the order in which students submitted their bids for discussion sections before the first semester. Strictly speaking, this may not be random. However, since the vast majority of

\footnotetext{
${ }^{5}$ In a welcome letter, the university also suggests that students wait to bid until the orientation week.
} 
students submit their bids during a short period of time and since the timing of the bids does not affect the student's assignment to discussion section, this mechanism may be effectively uncorrelated with students' characteristics.

The assignment mechanism is not publicly known, neither to students nor to university officials. Thus, strategic behavior on the side of students or university officials to deliberately influence the assignment beyond the preference ranking seems unlikely. Importantly, balance tests reported below indicate that the mechanism is effectively random: conditional on stated preferences, we find almost no differences in observable characteristics between students that were assigned to different fields.

Table 2 reports field assignments by preference rankings. About $46 \%$ of students state business as their first choice. This means that business is oversubscribed, since only one-third of the papers are assigned to business. Thus, about one quarter of students whose first choice is business are assigned to economics or law instead. In contrast, students who state economics or law as their first preference are likely to be assigned to their preferred field. Students who do not provide a preference ranking are most likely assigned a paper in law $(75 \%)$ or in economics $(23 \%)$. We focus our subsequent analysis mainly on preference group 1, i.e. "Business, Economics, Law". This group includes the majority of students who did not receive their first choice and who were therefore allocated algorithmically to their field. ${ }^{6}$

Table 2: Field assignment by preference group

\begin{tabular}{llccc|c|c|c}
\hline \multirow{2}{*}{ Preference ranking } & \multicolumn{2}{c}{ Assigned field of first-year paper } & \multicolumn{2}{c}{} \\
\cline { 2 - 8 } & Business & Economics & Law & Total & Share (\%) & $\begin{array}{c}\text { Share } 1^{\text {st }} \\
\text { choice (\%) }\end{array}$ \\
\hline 1 & Business, Economics, Law & 2,461 & 533 & 235 & 3,229 & 34.9 & 76.2 \\
2 & Business, Law, Economics & 774 & 0 & 231 & 1,005 & 10.9 & 77.0 \\
3 & Economics, Business, Law & 21 & 1,999 & 40 & 2,060 & 22.3 & 97.0 \\
4 & Economics, Law, Business & 0 & 290 & 14 & 304 & 3.3 & 95.4 \\
5 & Law, Business, Economics & 2 & 0 & 725 & 727 & 7.9 & 99.7 \\
6 & Law, Economics, Business & 1 & 0 & 366 & 367 & 4.0 & 99.7 \\
7 & No preferences stated & 42 & 351 & 1,164 & 1,557 & 16.8 & - \\
\hline & Total & 3,301 & 3,173 & 2,775 & 9,249 & 100.0 & - \\
\hline
\end{tabular}

Note: Table contains all first-year students in the years 2002 - 2012. It does not include students who have a special status because of insufficient command of German. See Section 3 for details.

${ }^{6}$ Although preference group 7 would also provide sufficient variation, a high share of students in this group fails the first year (58\%), as they do not seem to be committed to their studies in the first place. Group 2 provides no information about exposure to economics, and had little effect on our estimates of the effect of exposure to law. 


\section{Data and descriptive statistics}

The data are based on administrative student records of the University of St. Gallen. These records cover all students from the entering cohorts 2002 - 2012. They cover enrollment, major choice, courses, grades, and degrees. They also include limited socio-demographic characteristics, such as age, gender, nationality, canton of the student's high school, native language, and whether a student had to take an entrance exam. ${ }^{7}$

The data contain detailed information on the first-year paper. For every student we know the preference ranking, the assigned field, and the identifier for their discussion section. In addition, the data include the meeting times of the discussion sections as well as the respective teaching assistant identifiers. All the above information can be merged by a unique student identifier.

We exclude students with limited knowledge of German, who have a special status (about $4 \%$ of all students). These students wait until their third semester to write the paper. ${ }^{8}$

Table 3 shows the relationship between preference rankings and majors declared at the end of the first year. The major categories are non-exclusive and the shares do not add up to one since students with a high GPA can choose double majors. There is a strong association between students' preferences and their subsequent major choices. Among students in preference group 1, a majority majors in business. However, stated preference rankings do not map one-to-one onto chosen majors, which might indicate that students learn about the different fields during their first year and adjust their major choice accordingly. The table also reveals that a substantial share of students does not complete the first year successfully, i.e. students either drop out or repeat the first year. In order to pass the first year, students have to complete all requirements with

\footnotetext{
7 Admission to studies at University of St. Gallen is unrestricted for all Swiss citizens and foreign nationals who obtained their high school degree (Matura) in Switzerland. Foreign students without a Swiss high school degree have to pass an entry exam and have to pay higher tuition. The acceptance rate is about $20 \%$. Therefore, this group of students is positively selected.

${ }^{8}$ Students can also extend the first year because of other hardship, such as family obligations or health problems. However, the vast majority extends because of language insufficiency. The application for the extended first year has to be submitted during the first two weeks of the first semester. Moreover, we exclude 13 students due irregularities in their enrollment data.
} 
sufficiently high grades. ${ }^{9}$ If students do not pass the first year, they can attempt the entire first-year curriculum one more time.

Table 3: Major choice by preference groups for first-year paper field

\begin{tabular}{lcccccc}
\hline \multirow{2}{*}{ Preference Group (Ranking) } & Business & Economics & Law & Int. Affairs & $\begin{array}{c}\text { Law and } \\
\text { Economics }\end{array}$ & Failed \\
\cline { 2 - 7 } & 0.55 & 0.06 & 0.01 & 0.06 & 0.03 & 0.32 \\
\hline 1 Business, Economics, Law & 0.42 & 0.03 & 0.03 & 0.07 & 0.07 & 0.40 \\
2 Business, Law, Economics & 0.37 & 0.22 & 0.01 & 0.14 & 0.03 & 0.28 \\
3 Economics, Business, Law & 0.16 & 0.22 & 0.04 & 0.19 & 0.08 & 0.34 \\
4 Economics, Law, Business & 0.16 & 0.03 & 0.21 & 0.07 & 0.13 & 0.41 \\
5 Law, Business, Economics & 0.13 & 0.08 & 0.16 & 0.11 & 0.17 & 0.38 \\
6 Law, Economics, Business & 0.25 & 0.06 & 0.02 & 0.07 & 0.03 & 0.58 \\
7 No Preferences Stated & 0.39 & 0.10 & 0.03 & 0.09 & 0.05 & 0.37 \\
\hline Total
\end{tabular}

Note: Table contains all regular first-year students in the cohorts $2002-2012$. Shares correspond to major choices after the first year. 'Failed' refers to students who do not complete the first year successfully. Groups are overlapping since students with a first year GPA of 5.0 (with 1.0 being the lowest possible grade and 6.0 the highest) or higher are allowed to choose double majors.

Table 4 shows student and discussion section characteristics by assigned first-year paper field for preference group $1 .{ }^{10}$ Overall, $74 \%$ of students are male and on average 20.2 years old at enrollment. Foreign students represent approximately $27 \%$ of the students and $20 \%$ of students had to take the entry exam. Almost all students speak German as their native language. Only 1\% of the students are in the law track. ${ }^{11}$

Table 4 also provides balance tests, that is, tests of whether student characteristics vary according to the field to which they were assigned. The last column of the table reports p-values for tests of the null hypothesis that characteristics are the same for all groups. Among the 21 tests, there is one rejection at the 5-percent level, which is roughly what one might expect due to chance. These balance tests support the notion that, within preference group 1, assignment to field is effectively random.

\footnotetext{
${ }^{9}$ Students fail if they accumulate too many negative credit points. They receive negative credit points for each failed examination. Negative credit points are course credits weighted with the grade. Throughout the analysis, we restrict attention to students who are attempting the first year for the first time.

${ }^{10}$ Further descriptive statistics by preference group are provided in Table 10 in Appendix 1.

${ }^{11}$ Students who intend to study law can enter a specific law track. Instead of math it includes an additional law course in the first year. However, students can still choose all majors after the first year. In case students on the law track start a non-law major, they have to take the math course in the second year. Students that change from the general track to a law major have to take the additional law course.
} 
Table 4: Descriptive statistics and test of covariate balance (preference group 1)

\begin{tabular}{|c|c|c|c|c|c|}
\hline \multirow{2}{*}{ Variable } & \multicolumn{4}{|c|}{ Assigned field for first-year paper: } & \multirow[b]{2}{*}{$\mathrm{p}$-value } \\
\hline & Business & Economics & Law & Total & \\
\hline \multicolumn{6}{|l|}{ Student characteristics } \\
\hline Female $(0 / 1)$ & 0.27 & 0.26 & 0.24 & 0.26 & 0.62 \\
\hline Age (years) & 20.17 & 20.20 & 20.17 & 20.18 & 0.92 \\
\hline Foreign national $(0 / 1)$ & 0.27 & 0.26 & 0.25 & 0.27 & 0.72 \\
\hline Entry exam $(0 / 1)$ & 0.21 & 0.20 & 0.20 & 0.21 & 0.92 \\
\hline \multicolumn{6}{|l|}{ High school degree from } \\
\hline Canton St. Gallen $(0 / 1)$ & 0.14 & 0.15 & 0.14 & 0.14 & 0.92 \\
\hline Canton Zuerich $(0 / 1)$ & 0.17 & 0.16 & 0.14 & 0.16 & 0.60 \\
\hline Other German speaking canton $(0 / 1)$ & 0.42 & 0.44 & 0.47 & 0.43 & 0.24 \\
\hline Non-German speaking canton $(0 / 1)$ & 0.02 & 0.02 & 0.01 & 0.02 & 0.12 \\
\hline Non-Swiss institution $(0 / 1)$ & 0.25 & 0.23 & 0.24 & 0.25 & 0.67 \\
\hline German mother tongue $(1 / 0)$ & 0.95 & 0.96 & 0.97 & 0.96 & 0.58 \\
\hline Law track $(0 / 1)$ & 0.01 & 0.01 & 0.02 & 0.01 & 0.50 \\
\hline Contributed to student aid fund $(0 / 1)$ & 0.08 & 0.08 & 0.07 & 0.08 & 0.85 \\
\hline \multicolumn{6}{|l|}{ Discussion section characteristics } \\
\hline Morning session $(0 / 1)$ & 0.45 & 0.46 & 0.44 & 0.45 & 0.94 \\
\hline Afternoon session $(0 / 1)$ & 0.32 & 0.35 & 0.36 & 0.33 & 0.52 \\
\hline Evening session $(0 / 1)$ & 0.22 & 0.19 & 0.20 & 0.22 & 0.33 \\
\hline \multicolumn{6}{|c|}{ First semester teaching assistant (TA) characteristics } \\
\hline Female business TA $(0 / 1)$ & 0.44 & 0.44 & 0.37 & 0.43 & 0.35 \\
\hline Female economics TA $(0 / 1)$ & 0.08 & 0.09 & 0.05 & 0.08 & 0.25 \\
\hline Female law TA $(0 / 1)$ & 0.18 & 0.19 & 0.17 & 0.18 & 0.90 \\
\hline Experienced business TA $(0 / 1)$ & 0.89 & 0.90 & 0.91 & 0.89 & 0.77 \\
\hline Experienced economics TA $(0 / 1)$ & 0.87 & 0.88 & 0.76 & 0.86 & 0.02 \\
\hline Experienced law TA $(0 / 1)$ & 0.96 & 0.96 & 0.94 & 0.96 & 0.80 \\
\hline
\end{tabular}

Note: Table contains all regular first-year students in preference group 1 in the cohorts $2002-2012(3,229$ observations). Students have the option to donate a small amount to a student aid fund when paying their tuition fee. The indicator "contributed to student aid fund" here refers to students donating with their first tuition payment. Information on donations is only available from 2006 onwards The morning, afternoon, and evening session indicators correspond to the meeting time of respective discussion section. The experience of the teaching assistants indicates if teaching assistants have taught the same class at least once before. P-values are based on the F-statistics of a regression of the covariates on dummies for the assigned field with business as reference category.

\section{$4 \quad$ Empirical strategy}

Given quasi-random assignment to the field of the first-year paper within preference group 1, we estimate the effects of exposure to a field on major choice with a straightforward linear model. Our baseline specification is

$$
\text { major }_{i}=\beta_{0}+\beta_{1} * \text { field }_{\text {econ }_{i}}+\beta_{2} * \text { field }_{\text {law }_{i}}+\varepsilon_{i}
$$

where major $_{i}$ is an indicator variable whether student $i$ chooses a specific major after the first year. For instance, for economics the variable equals one if the student declares an economics 
major and zero otherwise (zero includes students who fail the first year). The categories are nonexclusive because some students major in two fields. field_econ $i$ and field_law $i$ are dummy variables indicating whether a student was assigned to economics or law (business is the omitted group). $\beta_{0}$ captures the probability that a student starts a specific major if she is assigned to business. $\beta_{1}$ and $\beta_{2}$ capture the change in this probability if a student is assigned to economics or law respectively. We also estimate the model conditional on baseline covariates. ${ }^{12}$ In Section 5.2 .3 we present a series of robustness checks. For all specifications we report Huber-White standard errors that are robust to heteroskedasticity and to correlation of the disturbances within discussion sections.

\section{Results}

\subsection{Main results}

Before we show our main results, we demonstrate what would happen if we ignored self-selection into exposure, that is, self-selection into the field in which the student writes her first-year paper. To do so, we regress major choices on assignment to paper field in the full sample, without conditioning on preferences. Although in our setting students cannot freely choose the field of their first-year paper, they influence their assignment via their preference ranking, and students whose first choice is either economics or law generally get that choice.

Table 5: Naïve OLS estimates of field assignment for the first-year paper on major choice

\begin{tabular}{lcccccc}
\hline & \multicolumn{7}{c}{ Major } \\
\cline { 2 - 7 } & Business & Economics & Law & Int. Affairs & $\begin{array}{c}\text { Law and } \\
\text { Economics }\end{array}$ & Failed \\
\hline Econ. Paper & $\begin{array}{c}-0.142^{* * *} \\
(0.013)\end{array}$ & $\begin{array}{c}0.135^{* * *} \\
(0.008)\end{array}$ & $\begin{array}{c}0.001 \\
(0.002)\end{array}$ & $\begin{array}{c}0.059^{* * *} \\
(0.007)\end{array}$ & $\begin{array}{c}-0.003 \\
(0.005)\end{array}$ & $\begin{array}{c}-0.026^{* *} \\
(0.013)\end{array}$ \\
Law paper & $\begin{array}{c}0.263^{* * *} \\
(0.012)\end{array}$ & $\begin{array}{c}0.005 \\
(0.006)\end{array}$ & $\begin{array}{c}0.078^{* * *} \\
(0.006)\end{array}$ & $\begin{array}{c}0.016^{* *} \\
(0.007)\end{array}$ & $\begin{array}{c}0.043^{* * *} \\
(0.006)\end{array}$ & $\begin{array}{c}0.117^{* * *} \\
(0.013)\end{array}$ \\
\hline $\begin{array}{l}\text { Major share (mean of } \\
\text { dependent variable) }\end{array}$ & 0.387 & 0.096 & 0.034 & 0.086 & 0.048 & 0.372 \\
$\mathrm{~N}$ & 9249 & 9249 & 9249 & 9249 & 9249 & 9249 \\
\hline $\mathrm{N}$
\end{tabular}

Note: Sample includes all regular first year students in the cohorts 2002-2012. Values in () are robust standard errors clustered at the discussion section level. Statistical significance is indicated as $* 0.1 * * 0.05 * * * 0.01$. Dependent variables are binary indicators that take 1 if a student started the respective major after the first year or failed the first year, or 0 otherwise.

${ }^{12}$ For the specification with additional covariates, we provide corresponding mean marginal effects from a probit model in Appendix 1. Results are almost identical. 
Table 5 presents these estimates. The results suggest that writing the paper in economics decreases the probability of majoring in business by 14.2 percentage points and increases the probability of majoring in economics by 13.5 percentage points. Similarly, they suggest that writing a paper in law increases the probability of majoring in law by 7.8 percentage points. However, these estimates confound the causal effect of exposure with self-selection, and as we see below, greatly overstate the effect of exposure. ${ }^{13}$

Table 6: Effects of field assignment for the first-year paper on major choice

\begin{tabular}{lcccccc}
\hline & \multicolumn{7}{c}{ Major } \\
\cline { 2 - 7 } & Business & Economics & Law & Int. Affairs & $\begin{array}{c}\text { Law and } \\
\text { Economics }\end{array}$ & Failed \\
\hline Econ. Paper & -0.001 & $0.027^{* *}$ & 0.003 & 0.001 & 0.008 & -0.023 \\
Law paper & $(0.024)$ & $(0.013)$ & $(0.004)$ & $(0.011)$ & $(0.008)$ & $(0.023)$ \\
& 0.053 & 0.011 & $0.016^{*}$ & -0.019 & 0.001 & $-0.056^{*}$ \\
& $(0.035)$ & $(0.017)$ & $(0.009)$ & $(0.013)$ & $(0.010)$ & $(0.033)$ \\
Econ. Paper & \multicolumn{7}{c}{ Panel 1: without covariates } \\
Law paper & -0.004 & $0.028^{* *}$ & 0.003 & 0.001 & 0.007 & -0.020 \\
& $(0.023)$ & $(0.013)$ & $(0.003)$ & $(0.011)$ & $(0.008)$ & $(0.022)$ \\
& 0.046 & 0.011 & $0.013^{*}$ & -0.017 & 0.000 & -0.043 \\
Major share (mean of & $(0.034)$ & $(0.017)$ & $(0.007)$ & $(0.013)$ & $(0.011)$ & $(0.033)$ \\
dependent variable) & 0.555 & 0.059 & 0.007 & 0.056 & 0.026 & 0.321 \\
N & 3229 & 3229 & 3229 & 3229 & 3229 & 3229 \\
\hline
\end{tabular}

Note: Values in 0 are robust standard errors clustered at the discussion section level. Statistical significance is indicated as * $0.1 * * 0.05 * * * 0.01$. Dependent variables are binary indicators that take 1 if a student started the respective major after the first year or failed the first year, or 0 otherwise. Included covariates in Panel 2 are age at enrollment, and binary indicators for foreign nationality, entry exam, sex of the student, German native speaker, canton in which high school diploma was obtained (St. Gallen, Zurich, other German speaking cantons, Non-German speaking cantons), law track, timing of discussion sections, sex of the first semester teaching assistant in each field, experience of the first semester teaching assistant in each field (whether the teaching assistant taught the class before). Table 11 in Appendix 1 presents corresponding marginal effects from a probit model. The estimation sample includes only students in preference group 1.

In Table 6 and below we restrict the analyses to preference group 1. Thus, these estimates of the effects of the first-year paper assignment on major choice are identified by the quasi-random assignment of students to fields described above. Panel 1 presents results from the baseline specification without covariates. Being assigned to an economics paper increases the probability of

\footnotetext{
13 Self-selection would be even stronger if students could freely choose the first-year paper field. To approximate that scenario, we estimate the same regressions only for students that are assigned to their first choice. As expected, the estimated coefficients are even larger. The results are available upon request from the authors.
} 
majoring in economics by 2.7 percentage points, which is large in relation to the share of economics students among students in the estimation sample. Similarly, being assigned to the law paper increases the probability of majoring in law by 1.6 percentage points. Panel 2 in Table 6 reports the results of the baseline specification conditional on covariates. The results are similar. Exposure to economics leads some students to major in economics, and exposure to law leads some students to major in law.

Now consider the remaining major choices. Being assigned to economics does not significantly alter the decision to study any other fields. Being assigned to law reduces the probability of failing the first year by 5.6 percentage points. This effect is marginally significant in Panel 1, and smaller and insignificant in Panel 2. A tentative explanation is that writing in law may be easier, because law papers follow a more standardized template than papers in other fields. If so, then students may be able to spend less time on their paper and more time studying for exams.

\subsection{Additional Results}

\subsubsection{First-year grades}

We investigate the effect of the student's paper assignment on her first-year grades in the three core courses. Students take first-semester exams from mid-January to mid-February and secondsemester exams from mid-June to mid-July. The first-year paper is assigned in December, approximately one month before the first-semester exam period, and so could affect grades in both terms.

Such effects could be either direct or indirect. One possibility is that, while writing the paper, the student might learn something directly applicable to her exams. The paper might also stimulate her interest in the field, leading her to study more. More indirectly, easier fields may give students more time to study for exams, as mentioned above.

Table 7 displays regression results of grades in the core courses on the first-year paper field. For ease of interpretation, we standardized grades to mean zero and standard deviation one. Assignment to an economics paper increases the grade in economics by about 0.11 standard deviations in both semesters. Students assigned to law have 0.13 standard deviation higher grades in business than those assigned to business in the first semester and 0.15 standard deviation higher grades in the second semester. The effect on the law grade is insignificant but sizeable in both 
semesters. These estimates point to a mix of direct and indirect effects, but it is impossible to fully disentangle them.

Table 7: Effects of field assignment for the first-year paper on first-year grades

\begin{tabular}{|c|c|c|c|c|}
\hline & \multicolumn{4}{|c|}{ First year core grades } \\
\hline & Missing grade & Business & Economics & Law \\
\hline \multicolumn{5}{|c|}{ Panel 1: first semester grades (fall) } \\
\hline \multirow[t]{2}{*}{ Econ. Paper } & -0.001 & $0.091 * *$ & $0.115^{* *}$ & 0.067 \\
\hline & $(0.008)$ & $(0.046)$ & $(0.046)$ & $(0.049)$ \\
\hline \multirow[t]{2}{*}{ Law paper } & $-0.018^{* *}$ & $0.133^{* *}$ & 0.048 & 0.090 \\
\hline & $(0.008)$ & $(0.067)$ & $(0.069)$ & $(0.060)$ \\
\hline Mean of dependent variable & 0.029 & 0.081 & 0.059 & 0.022 \\
\hline $\mathrm{N}$ & 3229 & 3160 & 3158 & 3167 \\
\hline \multicolumn{5}{|c|}{ Panel 1: second semester grades (spring) } \\
\hline \multirow[t]{2}{*}{ Econ. Paper } & 0.002 & 0.002 & $0.114^{* *}$ & 0.067 \\
\hline & $(0.021)$ & $(0.050)$ & $(0.050)$ & $(0.051)$ \\
\hline \multirow[t]{2}{*}{ Law paper } & -0.018 & $0.151 * *$ & 0.018 & 0.102 \\
\hline & $(0.026)$ & $(0.070)$ & $(0.076)$ & $(0.068)$ \\
\hline Mean of dependent variable & 0.179 & 0.071 & 0.026 & 0.000 \\
\hline $\mathrm{N}$ & 3229 & 2675 & 2677 & 2669 \\
\hline
\end{tabular}

\subsubsection{Results by sex}

Next we consider heterogeneous responses to the assigned paper field. A growing number of studies document large sex differences in major choices (Gemici and Wiswall 2014; Turner and Bowen 1999; Zafar 2013; Wiswall and Zafar 2015). To ask whether exposure to fields differentially affects students according to sex, we estimate Equation 1 separately for female and male students. Table 8 reports the results. For female students we find no significant effect of being assigned to write an economics paper. However, the probability of majoring in law increases by 4.7 percentage points among women assigned to write a law paper. On the contrary, male students react to economics rather than to law. Being assigned to an economics paper increases the probability that a male student majors in economics by 3.2 percentage points. ${ }^{14}$

\footnotetext{
14 Although the differences in the estimates by sex are large, they are statistically insignificant.
} 
Table 8: Effects of field assignment for the first-year paper on major choice by student sex

\begin{tabular}{|c|c|c|c|c|c|c|}
\hline & \multicolumn{6}{|c|}{ Major } \\
\hline & Business & Economics & Law & Int. Affairs & $\begin{array}{c}\text { Law and } \\
\text { Economics }\end{array}$ & Failed \\
\hline \multicolumn{7}{|c|}{ Panel 1: female students } \\
\hline \multirow[t]{2}{*}{ Econ. Paper } & 0.011 & 0.016 & 0.008 & -0.025 & -0.000 & -0.008 \\
\hline & (0.048) & $(0.022)$ & $(0.010)$ & $(0.025)$ & $(0.015)$ & $(0.046)$ \\
\hline \multirow[t]{2}{*}{ Law paper } & 0.065 & 0.005 & $0.047^{*}$ & -0.029 & -0.011 & -0.061 \\
\hline & $(0.080)$ & (0.031) & $(0.029)$ & $(0.031)$ & $(0.018)$ & $(0.073)$ \\
\hline \multirow{2}{*}{$\begin{array}{l}\text { Major share (mean of } \\
\text { dependent variable) } \\
\mathrm{N}\end{array}$} & 0.477 & 0.052 & 0.011 & 0.076 & 0.028 & 0.377 \\
\hline & 849 & 849 & 849 & 849 & 849 & 849 \\
\hline \multicolumn{7}{|c|}{ Panel 2: male students } \\
\hline \multirow[t]{2}{*}{ Econ. Paper } & -0.006 & $0.032^{* *}$ & 0.001 & 0.011 & 0.010 & -0.027 \\
\hline & $(0.027)$ & $(0.015)$ & (0.004) & $(0.013)$ & $(0.010)$ & $(0.024)$ \\
\hline \multirow[t]{2}{*}{ Law paper } & 0.046 & 0.012 & 0.007 & -0.014 & 0.005 & -0.052 \\
\hline & (0.038) & (0.018) & (0.008) & (0.014) & $(0.013)$ & $(0.036)$ \\
\hline \multirow{2}{*}{$\begin{array}{l}\text { Major share (mean of } \\
\text { dependent variable) } \\
\mathrm{N}\end{array}$} & 0.583 & 0.061 & 0.005 & 0.048 & 0.025 & 0.300 \\
\hline & 2380 & 2380 & 2380 & 2380 & 2380 & 2380 \\
\hline
\end{tabular}

Note: Values in 0 are robust standard errors clustered at the discussion section level. Statistical significance is indicated as $* 0.1 * * 0.05 * * * 0.01$. Dependent variables are binary indicators that take 1 if a student started the respective major after the first year of failed first year, or 0 otherwise.

\subsubsection{Threats to internal validity}

As discussed before, conditional on the student's preference ranking, her assignment to a field depends on two types of variation involving her sort order within her discussion section and the distribution of preferences within her discussion section. If either of these two types of variation is correlated with unobserved factors that also influence her choice of major, our estimates may be biased. Although the balance tests from Table 4 suggest that the assignment procedure is close to random, we nevertheless consider three robustness checks to address any remaining concerns regarding unobserved confounders.

The first two robustness checks address concerns regarding variation induced by the distribution of preference rankings of the other students in the discussion section. The first robustness check controls for first-semester teaching-assistant fixed effects. If students could somehow select into discussion sections based on preferences for teaching assistants, then our results could be biased. The reason is that if students with certain preferences for fields select specific teaching assistants, then the probability of being assigned to economics or law might be different for these students, 
which could lead to a correlation between treatment probability and unobserved preferences. Moreover, teaching assistants potentially influence students' preferences for fields (Bettinger and Long 2005; Bettinger and Long 2010). Such teaching-assistant effects could influence the distribution of preferences in the discussion section, and consequently the pool of students we observe in preference group 1 and the probability of being assigned to economics or law. For instance, if a particularly good teaching assistant in business raised interest in business, more students might state business as their first preference. However, these students would then be more likely to be assigned to an economics or law paper due to oversubscription of business. Our results could be biased if students' major choices were simultaneously affected.

To address this issue, we include teaching-assistant dummies in our major-choice regressions. The results appear in the top panel of Table 9. The estimates are generally similar to those in Table 6, which the exception that the effect of writing a law paper on majoring in law is not significant.

Next, we directly control for the share of students in each preference group in each discussion section. The probability of being assigned one's first, second, or third preference is a direct function of these shares. Hence, controlling for the distribution of preferences should take care of all factors that might create systematic differences in preferences between discussion sections. Besides any teaching assistant effects, students' preferences might partly depend on the preferences of other students in the discussion section (Ost 2010). Controlling for preferences within section accounts for such dependencies. Estimates are reported in Panel 2 of Table 9. Like the estimates in the top panel, these are largely similar to the estimates reported in Table 6.

Now consider variation in the sort order within sections. We think that it is reasonable to rule out strategic behavior, since students are uninformed about the link between their bid for section times and their assignment to the field of their first-year paper. Still, a potential concern is that students who are more organized or better informed may bid earlier for sections. As an unintended consequence, such students would be placed at a lower position on the assignment list. Within preference group 1, these students thus would be more likely to be assigned to economics or law. However, if organizational skills were correlated with preferences for economics (among students seeking to write a business paper), then assignment to both economics and law should be associated with a higher probability of majoring in economics. Likewise, if organizational skills were correlated with preferences for law, we should observe assignment to both law and 
economics to raise the likelihood that the student majors in law. However, we do not see either of these patterns in Table 6.

Table 9: Robustness checks for major choice

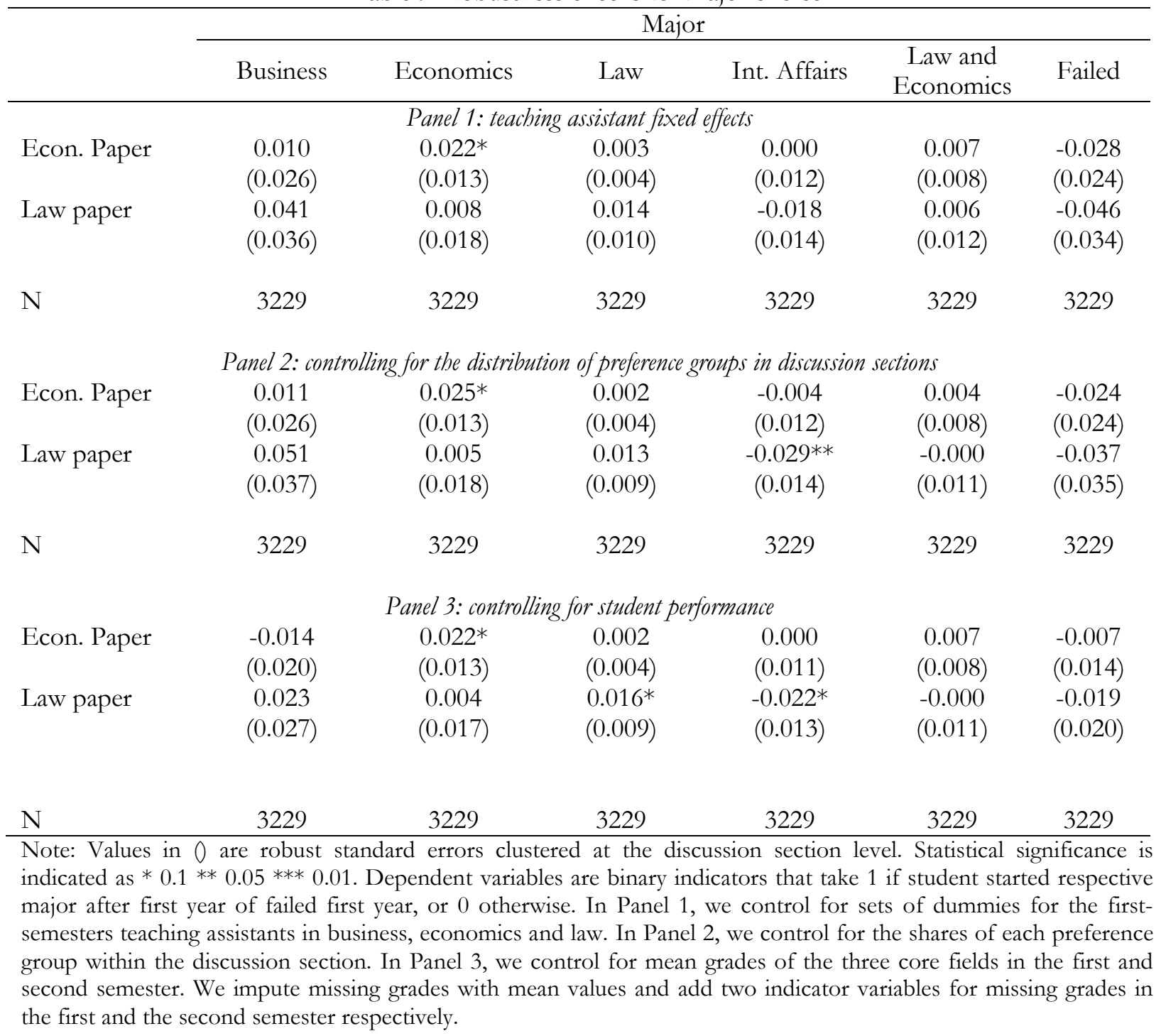

Finally, we control for students' first-year grades. This check should help to allay any remaining concerns that the effects of exposure on major choice might be driven by unobserved differences in ability or ambition that are correlated with the student's position in the sort order. In the regressions in Panel 3 of Table 9, we include mean grades from the three core fields in the first and second semester. We impute missing grades with mean values and add two indicator variables 
for missing grades in the first and second semester, respectively. ${ }^{15}$ We acknowledge that this provides a coarse and likely endogenous measure of the student's ability. The results from these regressions again accord closely with those presented in Table 6.

The results conditional on grades also make another useful point. As discussed in Section 5.2.1, the field of the first-year paper may cause differences in student performance. Yet, controlling for potentially endogenous grades does not change our main results on how exposure affects the probability of majoring in economics or law. However, the effects of exposure on the probability of passing the first year are now substantially smaller and statistically insignificant. These results provide some evidence that the field assignment affects major choice beyond improving students' grades and chances of succeeding in the first year.

\section{Conclusion}

This study analyzes the role of exposure to academic fields on students' choice of majors. We investigate whether exposure to economics or law induces students primarily interested in studying business to change their plans. To solve the selection problem that arises when students seek exposure to fields that already interest them, we exploit a natural experiment at a Swiss university.

At the University of St. Gallen, the first-year curriculum is almost the same for all students independent of their intended major. The main exception is the first year paper, which students write in either business, economics, or law. Due to oversubscription of business, the university assigns the field of the paper in a standardized way that is unrelated to student characteristics.

We find that exposure to economics substantially raises the probability of majoring in economics. Students whose preferred field is business are 2.7 percentage points more likely to major in economics after writing an economics paper. This equals $18 \%$ of the share of economics majors. Being assigned to write in law increases the probability of majoring in law by 1.6 percentage points. However, this effect is less robust.

How far these results would generalize to other settings is hard to judge. On the one hand, switching to economics may not be too great a stretch for students originally inclined toward business. It is easy to imagine that a student intending to major in English, for example, would be

15 Other specifications, excluding students with missing grades, or imputing missing grades with 1 (lowest possible grade) do not change these findings. Results are available from the authors upon request. 
less affected by writing even a lengthy paper on an economics topic. On the other hand, most students are exposed to new fields via coursework rather than research papers. Coursework in a new field may represent a more intensive form of exposure. If so, exposure via coursework may have greater effects than the exposure we analyze here.

Our results are in line with Stinebrickner and Stinebrickner (2014) and Zafar (2011), who suggest that students learn about their match-quality while in college. For instance, working on an economics topic might give students a better understanding of what economics is about and which skills are required. Nonetheless, we cannot conclusively unpack the mechanisms at work. Students might also expect to have an advantage in the respective major as they have learned more about the field.

Exposure to economics and law affects men and women differently. Whereas male students react to economics, female students respond to law. These findings are in line with Gemici and Wiswall (2014), Turner and Bowen (1999), and Zafar (2013), who document that women are generally less inclined than men to major in technical fields. Recently, economists have become concerned that female undergraduates tend to avoid economics. Goldin $(2013,15)$ raises the question of "how to sell economics to women without turning off men". Our results suggest that mere exposure is unlikely to draw more women to the field. 


\section{References}

Altonji, Joseph G. 1993. "The Demand for and Return to Education When Education Outcomes Are Uncertain." Journal of Labor Economics 11 (1): 48-83.

Altonji, Joseph G., Erica Blom, and Costas Meghir. 2012. "Heterogeneity in Human Capital Investments: High School Curriculum, College Major, and Careers." Annual Review of Economics 4 (1): 185-223.

Arcidiacono, Peter. 2004. “Ability Sorting and the Returns to College Major.” Journal of Econometrics, Higher education (Annals issue), 121 (1-2): 343-75.

Arcidiacono, Peter, V. Joseph Hotz, and Songman Kang. 2012. "Modeling College Major Choices Using Elicited Measures of Expectations and Counterfactuals." Journal of Econometrics 166 (1): 3-16.

Bettinger, Eric. 2010. To Be or Not to Be: Major Choices in Budding Scientists. NBER Chapters. National Bureau of Economic Research, Inc. http://ideas.repec.org/h/nbr/nberch/11593.html.

Bettinger, Eric P., and Bridget Terry Long. 2005. "Do Faculty Serve as Role Models? The Impact of Instructor Gender on Female Students.” American Economic Review P\&P 95 (2): 152-57.

Bettinger, Eric P, and Bridget Terry Long. 2010. "Does Cheaper Mean Better? The Impact of Using Adjunct Instructors on Student Outcomes." Review of Economics and Statistics 92 (3): 598-613.

Gemici, Ahu, and Matthew Wiswall. 2014. "Evolution of Gender Differences in Post-Secondary Human Capital Investments: College Majors.” International Economic Review 55 (1): 23-56.

Goldin, Claudia. 2013. "Notes on Women and the Undergraduate Economics Major." CSWEP Newsletter.

Grogger, Jeff, and Eric Eide. 1995. "Changes in College Skills and the Rise in the College Wage Premium." Journal of Human Resources 30 (2): 280-310.

Hamermesh, Daniel S., and Stephen G. Donald. 2008. "The Effect of College Curriculum on Earnings: An Affinity Identifier for Non-Ignorable Non-Response Bias.” Journal of Econometrics 144 (2): 479-91.

Hastings, Justine S., Christopher A. Neilson, and Seth D. Zimmerman. 2013. Are Some Degrees Worth More than Others? Evidence from College Admission Cutoffs in Chile. Working Paper 19241. National Bureau of Economic Research.

James, Estelle, Nabeel Alsalam, Joseph C. Conaty, and Duc-Le To. 1989. "College Quality and Future Earnings: Where Should You Send Your Child to College?” The American Economic Review 79 (2): $247-52$.

Joensen, Juanna Schrøter, and Helena Skyt Nielsen. 2015. "Mathematics and Gender: Heterogeneity in Causes and Consequences." The Economic Journal.

Kirkebøen, Lars, Edwin Leuven, and Magne Mogstad. 2014. Field of Study, Earnings, and Self-Selection. Working Paper 20816. National Bureau of Economic Research. http://www.nber.org/papers/w20816.

Malamud, Ofer. 2010. "Breadth versus Depth: The Timing of Specialization in Higher Education." LABOUR 24 (4): 359-90.

. 2011. "Discovering One's Talent: Learning from Academic Specialization." Industrial and Labor Relations Review 64 (2): 375-405.

Malgwi, Charles A., Martha A. Howe, and Priscilla A. Burnaby. 2005. 'Influences on Students' Choice of College Major." Journal of Education for Business 80 (5): 275-82. 
Montmarquette, Claude, Kathy Cannings, and Sophie Mahseredjian. 2002. "How Do Young People Choose College Majors?” Economics of Education Review 21 (6): 543-56.

Ost, Ben. 2010. "The Role of Peers and Grades in Determining Major Persistence in the Sciences." Economics of Education Review 29 (6): 923-34.

Stinebrickner, Ralph, and Todd Stinebrickner. 2014. "A Major in Science? Initial Beliefs and Final Outcomes for College Major and Dropout.” Review of Economic Studies 81 (1): 426-72.

Turner, Sarah E., and William G. Bowen. 1999. "Choice of Major: The Changing (unchanging) Gender Gap.” Industrial and Labor Relations Review 52 (2): 289-313.

Wiswall, Matthew, and Basit Zafar. 2015. "Determinants of College Major Choice: Identification Using an Information Experiment." Review of Economic Studies, Forthcoming.

Zafar, Basit. 2011. "How Do College Students Form Expectations?” Journal of Labor Economics 29 (2): 30148.

2013. “College Major Choice and the Gender Gap.” Journal of Human Resources 48 (3): 545-95. 


\section{Appendix 1: Further descriptive statistics and results}

Table 10: Descriptive statistics by preference group

\begin{tabular}{|c|c|c|c|c|c|c|c|c|}
\hline \multirow{2}{*}{ Covariates } & \multicolumn{8}{|c|}{ Preference group } \\
\hline & 1 & 2 & 3 & 4 & 5 & 6 & 7 & Total \\
\hline \multicolumn{9}{|l|}{ Student characteristics } \\
\hline Female $(0 / 1)$ & 0.26 & 0.43 & 0.27 & 0.32 & 0.48 & 0.46 & 0.28 & 0.31 \\
\hline Age (years) & 20.18 & 20.28 & 20.10 & 20.05 & 20.41 & 20.36 & 20.32 & 20.22 \\
\hline Foreign national $(0 / 1)$ & 0.27 & 0.15 & 0.32 & 0.24 & 0.13 & 0.17 & 0.23 & 0.24 \\
\hline Entry exam (0/1) & 0.21 & 0.09 & 0.27 & 0.18 & 0.08 & 0.10 & 0.15 & 0.18 \\
\hline \multicolumn{9}{|l|}{ High school degree from } \\
\hline Canton St. Gallen (0/1) & 0.14 & 0.17 & 0.13 & 0.20 & 0.24 & 0.18 & 0.16 & 0.15 \\
\hline Canton Zuerich $(0 / 1)$ & 0.16 & 0.18 & 0.16 & 0.22 & 0.17 & 0.19 & 0.21 & 0.18 \\
\hline Other German speaking canton $(0 / 1)$ & 0.43 & 0.49 & 0.36 & 0.35 & 0.46 & 0.46 & 0.41 & 0.42 \\
\hline Non-German speaking canton $(0 / 1)$ & 0.02 & 0.02 & 0.04 & 0.03 & 0.02 & 0.03 & 0.03 & 0.03 \\
\hline Non-Swiss institution $(0 / 1)$ & 0.25 & 0.13 & 0.31 & 0.20 & 0.12 & 0.14 & 0.19 & 0.23 \\
\hline German mother tongue $(1 / 0)$ & 0.96 & 0.97 & 0.92 & 0.92 & 0.97 & 0.95 & 0.93 & 0.94 \\
\hline Law $\mathrm{t}$ & 0.01 & 0.06 & 0.01 & 0.08 & 0.42 & 0.35 & 0.08 & 0.08 \\
\hline Contributed to student aid fund $(0 / 1)$ & 0.08 & 0.08 & 0.07 & 0.09 & 0.07 & 0.06 & 0.09 & 0.08 \\
\hline \multicolumn{9}{|l|}{ Discussion section characteristics } \\
\hline Morning session $(0 / 1)$ & 0.45 & 0.44 & 0.45 & 0.44 & 0.44 & 0.45 & 0.41 & 0.44 \\
\hline Afternoon session $(0 / 1)$ & 0.33 & 0.35 & 0.33 & 0.29 & 0.33 & 0.29 & 0.36 & 0.33 \\
\hline Evening session $(0 / 1)$ & 0.22 & 0.20 & 0.21 & 0.27 & 0.23 & 0.26 & 0.23 & 0.22 \\
\hline \multicolumn{9}{|c|}{ First semester teaching assistant (TA) characteristics } \\
\hline Female business TA $(0 / 1)$ & 0.43 & 0.42 & 0.42 & 0.44 & 0.43 & 0.44 & 0.42 & 0.43 \\
\hline Female economics TA $(0 / 1)$ & 0.08 & 0.09 & 0.08 & 0.06 & 0.09 & 0.11 & 0.11 & 0.09 \\
\hline Female law TA $(0 / 1)$ & 0.18 & 0.20 & 0.20 & 0.20 & 0.19 & 0.18 & 0.19 & 0.19 \\
\hline Experienced business TA $(0 / 1)$ & 0.89 & 0.90 & 0.90 & 0.84 & 0.89 & 0.89 & 0.89 & 0.89 \\
\hline Experienced economics TA $(0 / 1)$ & 0.86 & 0.87 & 0.86 & 0.84 & 0.88 & 0.89 & 0.89 & 0.87 \\
\hline Experienced law TA $(0 / 1)$ & 0.96 & 0.97 & 0.96 & 0.96 & 0.98 & 0.96 & 0.97 & 0.96 \\
\hline \multicolumn{9}{|c|}{$\begin{array}{l}\text { Note: Table contains all regular first-year students in the years 2002-2012. Preference groups } 1 \text { to } 7 \text { correspond to } \\
\text { "Business, Economics, Law", "Business, Law, Economics", "Economics, Business, Law", "Economics, Law, } \\
\text { Business", "Law, Business, Economics", "Law, Economics, Business", and "No preferences stated", respectively. } \\
\text { Students have the option to donate a small amount to a student aid fund when paying their tuition fee. The indicator } \\
\text { here refers to students donating with their first tuition payment. Information on donations is only available from } 2006 \\
\text { onwards. The morning, afternoon, and evening session indicators correspond to the meeting time of respective } \\
\text { discussion section. Experience of the teaching assistants indicates if teaching assistants have taught the same class at } \\
\text { least once before. }\end{array}$} \\
\hline
\end{tabular}


Table 11: Marginal effects from a probit model with covariates

\begin{tabular}{l} 
Business \\
\cline { 2 - 6 }
\end{tabular}




\section{Appendix 2: Explanation of Friday schedule for discussion sections}

Table 12 exemplifies the Friday schedule for the different discussion sections. This schedule abstracts from the semester. In the first semester, the fields refer to Business I, Economics I, and Law I, and in the second semester to Business II, Economics II, and Law II. Each section meets either in the morning, in the afternoon, or in the evening session. Each session has two time slots, i.e. the discussion sections attend two classes each Friday. While sections have the business class every week, economics and law classes alternate in even and odd weeks. Classes in the same time slots and in different fields are taught by distinct teaching assistants. One teaching assistant might teach several classes in the same field in different slots. Consider for example discussion sections 3 . These students meet in the morning session. From 8:15 am to 10:00 am, they attend the law class with Egli in even weeks, and the economics class with Vetter in odd weeks. Each week they have the business class with Müller from 10:15 am to 12: am.

Table 12: Simplified Friday schedule for discussion sections

\begin{tabular}{|c|c|c|c|c|c|}
\hline \multicolumn{2}{|c|}{ Morning session } & \multicolumn{2}{|c|}{ Afternoon session } & \multicolumn{2}{|c|}{ Evening session } \\
\hline $8: 15$ am - 10:00 am & 10:15 am - 12:00 am & 12:15 am - 2:00 pm & $2: 15 \mathrm{pm}-4: 00 \mathrm{pm}$ & 4:15 pm - 6:00 pm & 6:15 pm - 8:00 pm \\
\hline \multicolumn{6}{|c|}{ Even weeks } \\
\hline DS 1: Business (Müller) & DS 1: Economics (Sutter) & DS 5: Business (Smith) & DS 5: Economic (Nys) & DS 9: Business (Jost) & DS 9: Economics (Nur) \\
\hline DS 2: Business (Smith) & DS 2: Economics (Vetter) & DS 6: Business (Jost) & DS 6: Economics (Sost) & DS 10: Business (King) & DS 10: Economics (Pip) \\
\hline DS 3: Law (Egli) & DS 3: Business (Müller) & DS 7: Law (David) & DS 7: Business (Frank) & DS 11: Law (Franco) & DS 11: Business (Baum) \\
\hline DS 4: Law (Äpli) & DS 4: Business (Lohse) & DS 8: Law (Knaus) & DS 8: Business (Urs) & DS 12: Law (Sauder) & DS 12: Business (Lee) \\
\hline \multicolumn{6}{|c|}{ Odd weeks } \\
\hline DS 1: Business (Müller) & DS 1: Law (Egli) & DS 5: Business (Smith) & DS 5: Law (Peter) & DS 9: Business (Jost) & DS 9: Law (Sauder) \\
\hline DS 2: Business (Smith) & DS 2: Law (David) & DS 6: Business (Jost) & DS 6: Law (Meier) & DS 10: Business (King) & DS 10: Law (Denter) \\
\hline DS 3: Economics (Vetter) & DS 3: Business (Müller) & DS 7: Economics $(\mathrm{Ny})$ & DS 7: Business (Frank) & DS 11: Economics (Pip) & DS 11: Business (Baum) \\
\hline DS 4: Economics (Uhlen) & DS 4: Business (Lohse) & DS 8: Economics (Dan) & DS 8: Business (Urs) & DS 12: Economics (Nur) & DS 12: Business (Lee) \\
\hline
\end{tabular}

Note: DS1-DS12 refer to exemplary discussion sections. Teaching assistant names are in parenthesis. 


\section{Appendix 3: Further information on the first year paper Sample list of topics of first year papers}

Note that first year papers are mostly written in German. The following titles have been translated to English by the authors.

\section{Business}

- What chances and challenges does crowd-sourcing provide for the innovation management of SME?

- Facebook, Xing, and Youtube: Social networks - how they work and why they are successful

- Intrinsic motivation and creative work - why money is not sufficient

\section{Economics}

- The comeback of gold: why the financial crisis fuels the price of gold

- The economic importance of tourism for the canton of St. Gallen

- Foreigners take our jobs!? Discuss the effect of immigration on the labor market in Switzerland. Who are the winners and losers of immigration?

\section{Law}

- Prohibition of alcohol in soccer stadiums: Who (federal or state government) has subjectmatter jurisdiction to issue a ban on the consumption of alcohol in stadiums? Is such a ban in the public interest and is it proportionate?

- Does freedom to demonstrate exist in Switzerland?

- Is the ban of political posters on public ground legal? 


\section{Requirements and assessment criteria}

Scale

Approximately 15 pages, title page, table of contents, bibliography, index, etc., not included.

The paper is assessed along the following dimensions:

\section{How to deal with the topic}

Have the problems and the objectives been clearly defined? Is the train of thought consistently in line with the work on the problem? Is the weight accorded to individual chapters (breadth versus depth) appropriate? Are all propositions correct with regard to content?

\section{Structure of the work}

Does the work on the problem serve its purpose and is it systematic? Can the train of thought ("red thread") be readily understood? Is the argumentation consistent and oriented towards the development of your very own, well-reasoned conclusions?

\section{Academic quality of the work}

Is there a critical analysis and interpretation of the relevant literature, and are its arguments and conclusions weighed up appropriately? Are the scientific sources relevant to the topic assessed and processed appropriately, are the quotations correct and standardized, are the style and register appropriate?

\section{Formal quality of the work}

Clear, well-structured layout; correct spelling; visualization; correctly arranged lists: contents, figures, and literature.

\section{Overall impression}

What is the overall impression, taking into account the degree of difficulty of the problem and the support received? 


\section{Appendix 4: Illustration of the assignment mechanism}

This appendix explains how the assignment mechanism is implemented exactly. Table 13 shows a discussion section with six students and their preference rankings. In this section with six students, two students are assigned to each field. The algorithm assigns the fields by looping through the list of students up to three times:

1. Go through the list of students from top to bottom and assign everybody their first choice until a field is full. This assigns students 1, 2, 3, 6 their first preferences. Business is full after student 2 .

2. Go through the list again and assign those who did not get their first preference their second preference unless the field is full. Student 5 is assigned to economics, which is full now.

3. Go through the list again and assign the remaining students to their third preference. Assign students that did not state a preference ranking to the open slots. Student 4 is assigned to law.

Table 13: Example of discussion section with six students

\begin{tabular}{clccc}
\hline Order in section & \multicolumn{1}{c}{ Preference ranking } & $\begin{array}{c}\text { Assigned field: } \\
\text { 1 round }\end{array}$ & $\begin{array}{c}\text { Assigned field: } \\
\text { 2 round }\end{array}$ & $\begin{array}{c}\text { Assigned field: } \\
\text { 3 round }\end{array}$ \\
\hline 1 & Business, Economics, Law & Business & & \\
2 & Business, Law, Economics & Business & & \\
3 & Economics, Business, Law & Economics & & Law \\
4 & No preferences stated & & Economics & \\
5 & Business, Economics, Law & & & \\
6 & Law, Business, Economics & Law & & \\
\hline
\end{tabular}

